\title{
Student Voice to Improve Schools: perspectives from students, teachers and leaders in 'perfect' conditions
}

Authors: Mari-Ana Jones (Norwegian University of Science and Technology) and Sara Bubb (University College London Institute of Education)

Key Words: Student voice, pupil voice, children's rights, school improvement

\section{Abstract}

This paper explores the use of student voice to contribute to improving schools. Through the gathering of perspectives and experiences of staff and students, this paper considers how the responses to requirements for both student voice and school improvement interrelate and identifies challenges to be addressed. The research was conducted in Norway because, with its long-standing engagement with children's wellbeing and rights expressed through its comprehensive framework of legislation and allocation of resources, it has arguably created ideal conditions for students to be involved in improving schools. Findings revealed some recognition of the centrality of student voice in the enactment of democracy in schools: students and teachers had positive perceptions of student voice and school leaders were willing to incorporate student voice in school improvement processes. Current uses of student voice were, however, largely restricted to the operations of the student council for a range of reasons. The absence of alternative structures, time constraints and doubts about competence were reported, leading to student voice having little impact on school improvement, even in what might be considered 'perfect' conditions.

\section{Introduction}

This paper considers the relationship between student voice and the leadership of school improvement. Bron \& Veugelers (2014) note the centrality of student voice in educational policy in a number of countries but our research was conducted in Norway where it is perhaps strongest. The latest iteration of the national curriculum (2020) emphasises children's right to be heard, as specified in the United Nations Convention of the Rights of 
the Child (Unicef, 1990) and incorporated into Norwegian law in 2003. Through the gathering of perspectives and experiences of staff and students, this research considers how the responses to requirements for both student voice and school improvement interrelate and identifies challenges to be addressed.

The research presented here provides examples of how multiple understandings of student voice are manifested in practice, and how concerns about student voice as an accountability measure create obstacles to potentially positive connections with improving schools. The consideration of how student voice can contribute to improving schools adds to extensive and ongoing discussions about what constitutes better schools and how to go about achieving them.

The research questions at the centre of this study that took place in Norway are:

- What are the views of students, teachers and leaders about student voice?

- How do they think it is helping schools improve?

\section{Student voice}

Student / pupil voice is a term in common usage, but its conceptualisation is complex, reflected in the diversity of perceptions and experiences of student voice collected in this research. Cook-Sather (2006, p. 360) suggests that no 'clear and definite conception exists for student voice', and Arnot and Reay (2007, p. 311) describe the concept of student voice as 'problematic'. Some key themes emerge from the literature. The idea of 'partnership' is repeated (Flutter, 2007; Pedder and McIntyre, 2006; Thompson, 2009), as is the word 'consultation', explained by Rudduck and McIntyre (2007, p. 7) as distinct from participation and indicating a role in decision-making, supported by Quaglia and Corso (2014, p. xii). The connection with improving schools is explained by Fletcher $(2005$, p. 5), who describes student voice as 'authorizing them [students] to represent their own ideas, opinions, knowledge and experiences throughout education in order to improve our schools'. This definition is supported by Robinson and Taylor (2013, p. 33), who report students bringing about changes. However, Hall $(2017$, p. 7) identifies tension between students as 'consumers' - with their voices being elicited for quality control purposes - instead of their voices having 'power, authenticity and validity'. 
Since the United Nations Convention on the Rights of the Child (UNCRC), specifically Article 12 , the student voice research field has developed, making 'enormous strides' (Fielding, 2011, p. 4). Gonzalez, Hernandez-Saca and Artiles (2017, p. 468) report that 'student voice research continues to gain momentum', challenging the initial 'uncritical enthusiasm' for student voice work in education (Bourke and Loveridge, 2018, p. 3). Cook-Sather (2018, p. 17) describes the increasing complexity of the field as demonstrated by an expansion of terminology, the methodological and ethical considerations and the diversification of research informants and contexts.

There is little debate in the literature about whether students should be consulted and included in change processes in schools: the consensus is that they should be and that it makes a difference. Woods and Macfarlane (2017, p. 85) consider that, 'in great schools, student voice is strong throughout the school, through...student leadership teams...but also through day-to-day opportunities in every classroom'. Hargreaves and Shirley $(2009$, p. 82) propose students as 'partners of change' and Rodgers (2006, p. 230) suggests that 'a partnership means that teachers and students are working towards a shared goal: students' learning'. Keddie (2015, p. 227) argues that the 'thoughtful and serious consideration of student voice can yield substantial benefits for schools', attributing value to students as a 'significant resource for supporting school improvement'.

Concerns continue to be raised in the literature, however, about associations between student voice and school improvement. This is perhaps due to the differing traditions in the two fields; with student voice deriving from a democratic and emancipatory discourse, whilst school improvement is more readily associated with agendas of effectiveness and efficiency. Almost twenty years ago, Fielding (2001, p. 105) criticised 'tokenistic' student voice procedures which met requirements but perpetuated the status quo. Keddie (2015, p. 225) describes the 'astounding array of external 'excellence' indicators and measures' for schools and expresses unease about student voice being added to the list. Charteris and Smardon (2019) assert that student voice has now become inextricable from 'performative quality control' (p. 316) and suggest a type of 'ventriloquism' as student voice is defined by adults to suit the purpose of accountability (p. 318). Hall (2017, p. 180) favours a dialogue between school professionals and students which goes beyond institutional requirements. 
This research is situated within these tensions. It builds on existing evidence for the inclusion of teachers in school improvement work to bring about lasting and locally relevant positive change, but what might happen if students were also included?

\section{Context}

We chose Norway in which to study student voice and school improvement, because with its long-standing engagement with children's wellbeing and rights, expressed through its comprehensive framework of legislation and allocation of resources, it has arguably created the ideal conditions for students to be involved in improving schools. When practical considerations such as requirements and conditions are taken care of, how is student voice perceived and experienced, and importantly, what challenges remain?

Norway regularly tops global indexes on children's rights and childhood in general (Langford and Kirkeb $\varnothing 2019$, p. 44). It is one of a minority of countries which chose to incorporate the United Nations Convention on the Rights of the Child (UNICEF, 1989) fully into domestic law (2003), confirming its international reputation as having 'a general culture for the respect of rights' (Lundy, Kilkelly, \& Byrne, 2013, p. 453). Since the latter part of the nineteenth century, Norway has considered schools to be vital in the preparation of children to take part in democracy (Thuen, 2017, p. 124). From the age of seven, children can give their opinions in cases which affect their lives. They are involved in democratic processes at local and national level and there is a growing number of young people elected into local government. Norway is one of the richest countries in the world. It is the second highest spender on school education and has the third lowest student:teacher ratio in OECD countries (OECD, 2015). In 2017, the Act of Education (Research], n.d.) was amended to stipulate that 'all children have the right to a good school environment', detailing that schools must ensure this by listening to students.

However, despite extensive measures and its child-centred and democratic reputation (MacBeath, 2004, p. 20), implementation in Norway appears problematic. Two reports to the UN (Kidza Har Rett and Barns Rettigheter i Norge) in 2017 found that children are not heard in cases which directly affect them, in schools or in society. The Children's Ombudsman reported to the UN $(2017$, p. 18) that 'there is an ongoing lack of expertise in conversing with children and highlighting the views of children in several arenas 
including...the education sector'. These reports concur with other data collected from students in Norwegian schools. Annually, schools are required by Utdanningsdirektoratet (UDIR) to carry out an anonymous survey of their students' opinions, which is compulsory for students in Years 7, 10 and 11 and used in other year groups. Among the twelve categories of questions, 'student democracy and participation' is one in which schools score lowest (UDIR, 2019).

Consequently, UDIR is urging schools to act. 'Democracy and participation' are among the core principles in the 2020 Norwegian national curriculum, stating that 'children should experience that they are listened to in the daily life of school, that they have real influence and that they can affect that which concerns them' (UDIR, 2018). The requirements are that children should be heard in whole school matters as well as the daily work in the classrooms. The challenge is in ensuring this happens in practice.

Parallel to this is a heightening of expectations regarding school improvement. A white paper from 2016 (No.21, Kunnskapsdepartmentet) demonstrated the variation in quality between schools in Norway and explained the need for more stringent demands on local authorities to ensure school improvement; including decentralised professional development programmes, closer follow up and additional resources for innovation. The updated national curriculum stipulates that schools will ensure improvement through the development of professional learning communities in which colleagues reflect and learn together (UDIR, 2018). The national requirements for principals (UDIR, 2015) state that ensuring school improvement in line with external and internal needs is the responsibility of the principal, and that their ability to lead school improvement processes is decisive. These requirements are conveyed through a National Qualification for School Leaders, and the leadership of improvement is a key competency area.

School leaders in Norway are subject to a complex framework of legislation, requirements and expectations relating to both student voice and school improvement. If students are required to be heard and to influence all aspects of school life, it should follow that school improvement processes could be enriched by the inclusion of student voice. Indeed, it could be argued that a fundamental reason for student involvement is to bring about better schools. 
This research can be positioned in the understanding of schools as democratic, inclusive and transparent cultures (Dons, 2010, p. 88); as learning organisations, which include the voices of students. It presents the 'state of play' in three schools, identifying issues which are also likely to be present in other schools, in other contexts. If these are addressed, then there is more potential for student voice to contribute to improving schools.

\section{Methods and Methodology}

The research was conducted in three schools in a small city in Norway. School A is 'international', with students from 50 nationalities and English as the language of instruction, but which operates under Norwegian education laws, regulations and requirements. Schools B and C are Norwegian public schools. Although the research was conducted in Norwegian and English according to the language of the school, there are nuances of translation.

The research gathered qualitative data in three schools through focus groups and interviews. The research also included quantitative data collection in the form of an initial student questionnaire, which used agreement rating to gain a broader perspective on student voice. To some degree, the research design can be described as sequential explanatory (Robson \& McCartan, 2016, p. 178), in which the qualitative findings were used to enrich the questionnaire. In School A the responses in the questionnaire were discussed in the focus groups. In Schools B and C themes from the questionnaire were raised in focus groups and interviews. Participants in the research were volunteers and the number of those involved was intentionally small to facilitate inclusive and in-depth discussions.

In School A, an international school with 225 students aged 6 to 16, there were 153 (out of a possible 200) survey responses from students aged 10-16. There was a focus group of five students aged 13-14 and another focus group of three teachers. In School B, a local school with 330 students aged 6 to 12, there was a focus group of three students aged 12 and another of two teachers, and an interview with the principal. In School C, a local school with 615 students aged 6 to 12, there was a focus group of four students aged 12 and another of two teachers, and an interview with the assistant principal. 
Both breadth and depth were important to address the research questions. A mixed methods approach enabled the examination of research questions from several angles and thus improved the rigour of the research. Pring $(2015$, p. 61$)$ explains how a mixed methods approach is best suited to addressing the intricacies of multiplicity: 'the world of real life cannot be captured by either the one or the other [qualitative or quantitative] and indeed there must be an integration and overlapping of the two'.

Arthur et al (2012, p. 147) consider that 'mixed methods research entails a combination of qualitative and quantitative approaches with the ambition to generate a more accurate and adequate understanding of social phenomena'. Although accuracy is an incompatible ideal in a study designed to collect perspectives, in this case a mixed methods and comparative approach moves the study from 'snapshots' of individual opinions to enable a deeper analysis.

Ethical considerations in this research were considerable, due to the inclusion of children and the impossibility of ensuring anonymous participation in focus groups and interviews within each school. Following contact with the gatekeepers (the headteachers), voluntary informed consent was obtained from all participants, as well as the parents of the children. Questions have been raised about the ability of children to provide informed consent, but in this study particular care was taken to ensure all information provided was accessible and understandable. The inclusion of children in this research was vital. Lumby $(2012$, p. 237) suggests that they are often left out of research on leadership in schools, due to notions that they are immature, not competent to judge, overly suggestible as well as the ethical challenges of consent. In this process which is designed to map perceptions of student voice it would indeed seem unreasonable to omit children. This is supported by O'Neill (2018, p. 41), who argues that 'only children can provide or permit the collection of the requisite data on their own educational knowledge and experiences'.

\section{Findings}

The findings indicated that there is a diversity of perceptions of student voice both within and between schools. Whilst participants in all schools shared the notion that student voice involved listening to students, the arenas and channels for this listening differed. What 
students were allowed to have an opinion about - and the extent to which their opinions were taken into consideration - also varied.

\section{Are students listened to?}

In School A's questionnaire, most pupils were positive towards student voice and felt that students had opinions to contribute. As Figure 1 shows, $46 \%$ of respondents 'agreed' and $44 \%$ 'strongly agreed' that teachers should ask students' opinions. Without further questioning, it is difficult to know why $9 \%$ of respondents did not agree.

\section{Insert Figure 1}

Figure 1: Levels of agreement with the statement 'I think that teachers should ask students for their opinions about schools' (1=Strongly Disagree, 4=Strongly Agree) ( $n=153)$

I think that teachers should ask students for their opinions about school. 153 responses

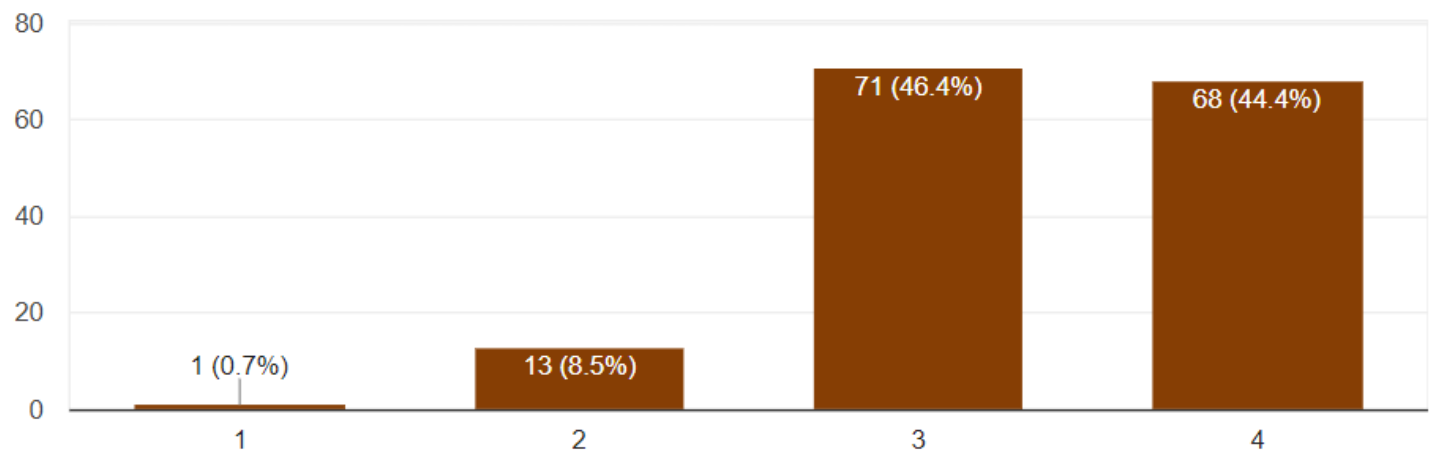

That students should be asked for their opinions and involved is supported by the qualitative data. Students, teachers and school leaders in all three schools agreed that student voice is important and useful. For example, a teacher in School A said, "It's like a basic need for a child, that their ideas are heard. It affects their happiness and their confidence" and a student in School C said, "It's really important that everyone gets to share their opinions. Everyone should be heard."

The findings suggest that participants across the three schools were interested in student voice, seeing it as an important part of their school communities. Many also connected student voice with processes to improve their school, although doubts were expressed 
about the reality of this in practice. One student in School A said, "The school is very good at listening to our opinions, however I feel like the school very rarely takes them into consideration and does anything about them."

Is student voice helping school improvement?

Whilst respondents were optimistic about students and teachers working together to improve schools, they were not overwhelmingly so. A third of students chose option 3 on the Likert scale (see Figure 2), indicating uncertainty about the possibility of students and teachers being able to bring about improvement together.

Insert Figure 2 and 3

Figure 2: Levels of agreement with the statement 'I think that students and teachers could work together to make schools better' (1=Strongly Disagree, $4=$ Strongly Agree) $(n=153)$

I think that students and teachers could work together to make schools better

\section{3 responses}

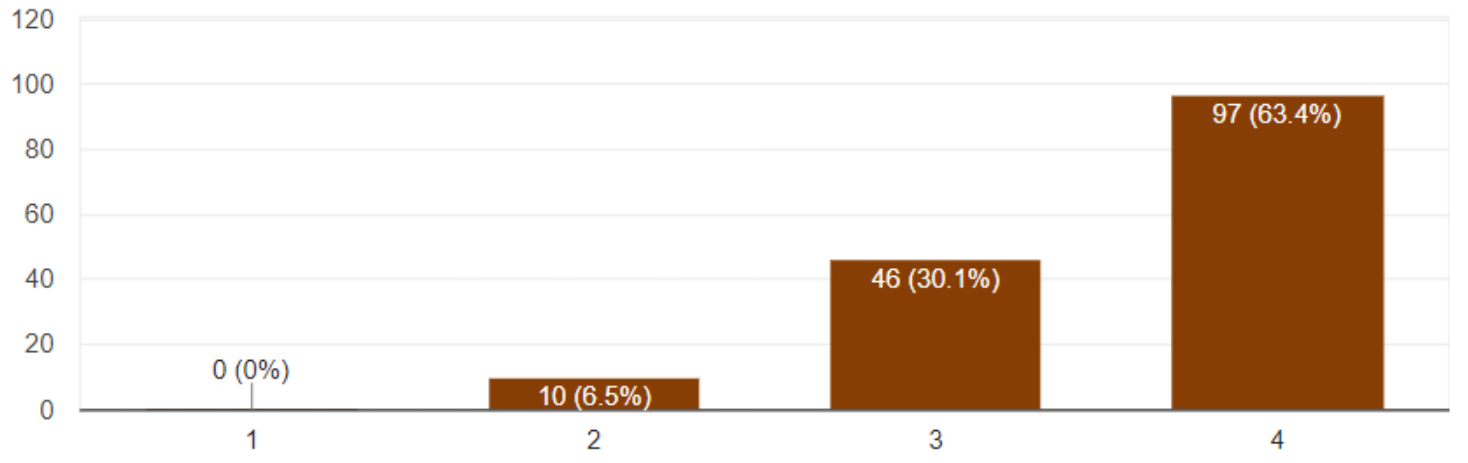


Figure 3: Levels of agreement with the statement 'I think that more improvements would happen at our school if teachers asked for and listened to students' opinions (1=Strongly

I think that more improvements would happen at our school if teachers asked for and listened to students' opinions

153 responses

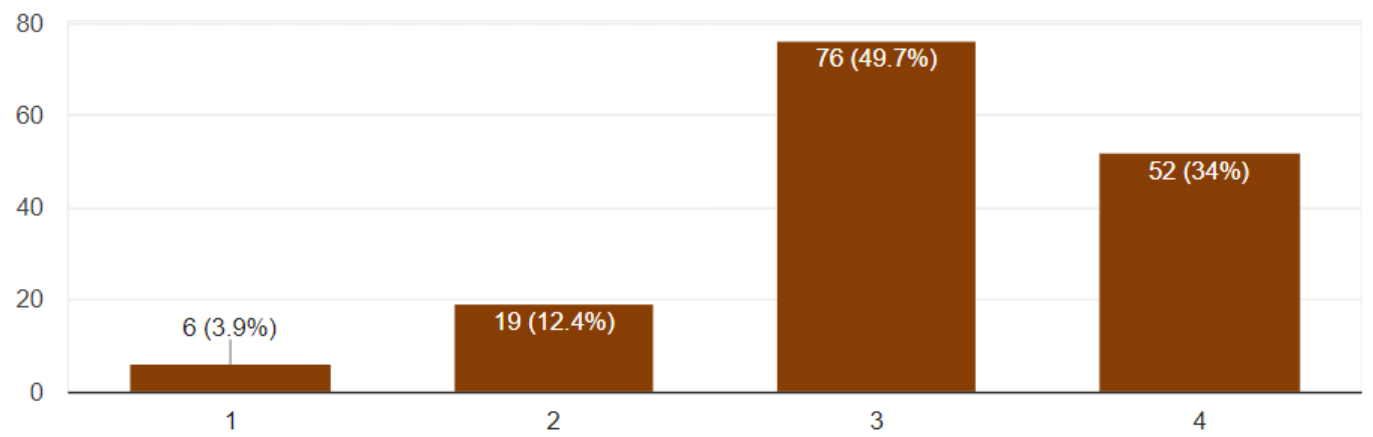

Disagree, 4=Strongly Agree) $(n=153)$

Responses revealed doubt regarding the potential of student voice to improve school, as seen in Figure 3. Although most students believed the school would get better if they were consulted, 25 selected option 1 or 2 , which at $16 \%$ is a significant minority.

These uncertainties warranted further investigation. It is concerning that with schools being expected to be collaborative learning communities (UDIR, 2018), students are sceptical of working with teachers to improve the school.

There was recognition that teachers and students had different ideas about how school should be. A student at School A said, "Teachers learnt at a different time from us. The school system should change with the generations." A teacher at School C said, "Adults see things in a different way from children."

Among respondents to the questionnaire there was some reticence regarding the ability of students to contribute; the majority only partially agreed that students know how to make schools better. This doubt was also reflected in the findings from the focus groups. Students were hesitant about whether their peers could contribute meaningfully:

I think that students could have some good input and could in some cases help, but we are kids. We complain and whine and I don't know that there is a way to set up communication and feedback from students that is productive and efficient. (Student, aged 15, School A) 
A student in School B was uncertain whether his peers would be responsible, saying: "If children just mess around then student voice is completely useless. If we're serious and in agreement about what we want, we can make changes". This was echoed by a student in School A: "[It is] difficult to get a completely rounded set of opinions from students. Perhaps newer or more shy students won't want to give their opinions". Might adults be able to positively influence how students view each other's contributions?

\section{Are student councils effective?}

The teachers and school leaders in all three schools used the student council as an example of the work their schools did to incorporate student voice. That all three schools have a student council is unsurprising: it is required by the Act of Education in Norway. In theory, thus, students in all schools in Norway have a formal channel through which they can express their opinions, as well as having the right to be heard. However, a student council can be tokenistic, serving to compartmentalise student voice. In Schools B and C, when asked about student voice, children in the focus groups immediately talked about the student council. They needed to be prompted to talk about any other aspect of student voice.

In School B, 12-year olds explained the selection process for the student council. Students submit an application for the position and then the teachers decide who will stand for election in the classes: "It is usually only the best in the class who apply to be student council representatives" and "Maybe the teachers won't let students be part of student council if they think they won't take it seriously". As one said, "It's the teachers who have the final decision, there's no point complaining".

Students said that the agenda for the student council meeting was decided by the teacher in charge, although students were able to make suggestions. The teachers in School B confirmed the opinions of the children, saying, "When cases come up for discussion in the student council, it's the teacher in charge who decides what is taken forward to the school leadership ... She knows when there is a point of taking something forward and when there isn't." They indicated that there is a degree of variance in how teachers prioritise the student council, suggesting that teachers are the deciding factor in the potential of the student council to change things. One teacher said, "We have class meetings where the 
students have suggestions for what the student council should discuss. The teachers try to guide during these meetings and stop the students when they have suggestions for trampolines and swimming pools. But the class meetings are run very differently depending on the teacher."

Time was cited as a barrier to the effective impact of student councils. A teacher in School B said:

We don't have time in staff meetings to take up things that come from student council. We have access to minutes from the meetings because the students come around to talk to the classes about them. But there is a difference among teachers how much time is used on this throughout the school.

Student councils in the three schools seemed to be somewhat limited in their scope and largely under the control of adults. They did, however, serve to provide a framework for students to give their opinions. At least the student council members felt that issues raised might be taken forward. In School A, when children were asked more informally about their views, a lack of structure appeared to create problems when they felt unheard. For example, a 13-year-old said,

When we give our opinion, teachers say "yeah, yeah we'll do something about it later" and then they never end up doing anything. That makes me feel annoyed. If they are going to use class time to ask us and then not do anything about it then it's a waste of time. If teachers aren't going to do anything about our opinion, then don't ask us.

Adults and students experience school life, and the extent of participation, differently. For example, in School $\mathrm{C}$ the deputy head spoke with pride of involving the student council in refining the school's vision. However, the students interviewed for this research made no mention of it, suggesting that the impact was minimal. Teachers say they have given students opportunities to be heard and are willing to engage in dialogue. Students say that their views have not resulted in change. When there is a danger of opinions not being followed up, there may be feelings of dissatisfaction and pointlessness. If students' opinions are asked for and given, then there are expectations for action. 


\section{Why is it difficult for student voice to help school improvement?}

An array of evidence demonstrates that students do not feel heard. It appears that their views were rarely incorporated in school improvement processes. Participants in this research suggested a number of challenges which help to explain this.

The most significant difficulty reported by students was their teachers' expectation of respect and deference, which was also described by Mitra, Serriere and Stoicovy (2012). A 15-year-old in School A said, "I feel like teachers should be able to take criticism, especially when they're giving us criticism all the time. But I don't feel comfortable giving them any criticism as I don't know how they will take it". Some students in School C did not feel able to be honest: "Sometimes teachers ask us whether that was a good lesson, and I feel pressured to say yes and that I liked the lesson, even if I didn't like it." The assistant principal in the same school said, "I think that we just have to take it if students say they don't like the lesson. But I think it's mainly teachers who feel secure in themselves who ask the students. You need self-confidence to do that."

Teachers in School A reported that they were welcoming of criticism from students: "Why would we want to make lessons the students don't like?". However, they cited complexities: "Younger children can be so easily influenced by each other. They are likely to go with the group opinion." As a teacher in School C said, "I think that students could be more involved in the daily decision-making in lessons and in the school. But I think it's really difficult to achieve in practice."

The issue of translating ideals into practice was mentioned elsewhere. One teacher in School B said, "We try to involve the students in deciding learning strategies but it's difficult to achieve". Whilst the principal of School B acknowledged the value of students' contributions, the complexity of concepts such as assessment was an obstacle to effective discussions: "Students can be useful in telling us whether something is working, but they need to be trained...we need to have a shared understanding of concepts."

The teachers across the three schools consider time as a significant barrier. For instance, a teacher in School A said, 
Students might come to student council with excellent ideas, but then to support them to put them in practice takes a lot of time. In an ideal world we would let them run things, but it is not always practical.

It is in these comments that the tension between what schools are for and what schools are about (Moos, 2004, p. 6) is demonstrated. Teachers experience the tension of wanting to engage with student voice, but not having the time. They are concerned about the maturity of students, but perhaps if students were given the opportunities to learn skills of participation, then their age would become less problematic. Perhaps if teachers had more opportunity for training in working with student voice, they would be better able to facilitate student involvement. Likewise, there may be less of a gulf between the ways that teachers and students experience school if they were able to develop a shared understanding.

\section{Discussion}

School leaders have a mandate to lead school improvement, but they also should ensure that children are heard and can influence and participate in their own education. This research considered the potential for the responses to these two requirements to interact, so that school leaders can facilitate a contextually relevant and inclusive school improvement process through the active involvement of students. It has, however, already been established that this interrelationship is complex. Whilst Leek (2019, p. 174) argues that student participation impacts positively on their development and subsequently their school's performance, MacBeath (2004, p. 31) spoke of the challenge of democratic processes because student voice can be time-consuming and might inhibit progress in terms of academic results: 'a highly effective school may be one which is profoundly undemocratic'.

The findings indicate positivity towards student voice in general, and specifically regarding the use of student voice to improve schools. The adult participants in this research said that they wanted to engage in dialogue with their students. Teachers want to engage with students' opinions and when they do, they hear meaningful and exciting contributions which positively impact their practice. The school leaders interviewed were clear about their responsibilities and were keen to involve students. They see the potential of student voice in enabling the development of the student's character, in developing their own teaching 
practice and in the improvement of the school as a whole. Students reported that they not only want to be heard, but also to participate in improvement. They see this participation as making a significant difference to their experience of school. Giving their opinions is not enough; they want to be part of deciding.

All this is encouraging, but there were other findings. The participating schools were providing channels for students to contribute, but these were either too rigid, in the case of the student council, or lacking structure, in the case of the informal sharing of views. This created frustration and disappointment, as well as limiting students' awareness of the potential impact of their voices. One significant difference between the schools appeared to be the expectations of students; if students views are elicited, then they anticipate action. The biggest challenge for students was the actual or possible responses of the teachers. Although teachers said that they were ready to hear students' opinions, students experienced a structure which did not allow for them to work alongside teachers. For teachers, time and competence were significant. For school leaders, these all become their problems. As Higham and Djohari (2018) found, although teachers and leaders appeared to value democracy highly, its implementation in their schools is challenging and limited.

Whether these challenges are perceived by teachers and school leaders to outweigh the benefits of involving students remains unclear. Rudduck and Mclntyre (2007, p. 195) state 'it is clear that successful implementation depends very much on the culture of classroom and school'. The readiness of school leaders to take on these challenges could be decisive in the impact of student voice on school improvement. As Lincoln $(1995$, p. 89) wrote, 'teachers must be willing'. Rudduck and Fielding (2006, p. 225) go further in considering that 'the development of student participation in schools depends on teachers being prepared to 'see' young people differently'. This may depend on feelings of being threatened; one of the many challenges of the application of student voice research in practice is what Cook-Sather (2018) describes as the prioritisation of young people's agendas over those of adults. Busher (2006, p. 148) reminds us that 'bringing about change successfully...requires participants to understand the cultures of communities in which they are trying to enact change'. School leaders facilitating teachers and students to talk together is an important part of the process of improvement in schools. 
The scale of this research was limited to a relatively small number of participants in just three schools. It would be interesting to extend the research to greater numbers. There are questions raised by this research which merit further investigation. It would be pertinent to explore how schools and teachers can be supported to utilise student voice. Teachers reported feeling uncertain about how to engage effectively with student voice and research which considers the effectiveness of various strategies to achieve this would be useful. Contrasting and conflicting experiences of school by students and teachers likewise deserve more attention. Concerns about whether 'staff and students can meet as genuine partners' have been raised by Robinson and Taylor (2013, p. 44). There may be questions of status and authority, there may be questions of age and experience, there may be questions of individual personalities or even a distinct reluctance to engage in dialogue due to insecurities regarding competence. A richer understanding of these differences may assist schools in finding opportunities to 'create meaning together' (Fielding, 2001, p. 106).

\section{Conclusion}

This research has shown that students want to be heard, and that teachers and school leaders want to listen. Even in the most 'perfect' conditions however, there are challenges. Although schools in Norway have advantages, incentives and obligations to include students in improving schools, this research found that the perceptions of key stakeholders varied about the extent of student involvement in practice. The adults in this research had a rosier view of the impact of student voice than the children themselves. Students felt frustration, considering that they have a great deal to offer to improve schools, given the opportunity. As a 12-year-old in School B said, "The school is the students, not the building or the principal". 


\section{References}

Arnot, M., \& Reay, D. (2007). A Sociology of Pedagogic Voice: Power, inequality and pupil consultation. Discourse: Studies in the Cultural Politics of Education, 28(3), 311-325.

Arthur, J., Waring, M., Coe, R., \& Hedges, L. (2012). Research Methods and Methodologies in Education. London: SAGE.

Bourke, R, \& Loveridge, J. (2018). Using Student Voice to Challenge Understandings of Educational Research, Policy and Practice. In R Bourke \& J. Loveridge (Eds.), Radical Collegiality Through Student Voice (pp. 1-16). Springer Singapore.

Bron, J., \& Veugelers, W. (2014). Why we need to involve our students in curriculum design: Five arguments for student voice. Curriculum and Teaching Dialogue, 16(1), 125-159.

Busher, H. (2006). Understanding Educational Leadership. Maidenhead: Open University Press.

Charteris, J., \& Smardon, D. (2019). The politics of student voice: unravelling the multiple discourses articulated in schools. Cambridge Journal of Education, 49(1), 93-110.

Cook-Sather, A. (2006). Sound, Presence, and Power: " Student Voice " in Educational Research. Curriculum Inquiry, 36(4), 359-390.

Cook-Sather, A. (2018). Tracing the Evolution of Student Voice in Educational Research. In Roseanna Bourke \& J. Loveridge (Eds.), Radical Collegiality Through Student Voice (pp. 17-38). Springer Singapore.

Dons, C. (2010). Styringsstruktur, ledelse og demokratisk dannelse i skolen [Management Structures, Leadership and Democratic Education in School]. In R. Andreassen, I. Irgens, \& E. Skaalvik (Eds.), Kompetent Skoleledelse [Competent School Leadership] (pp. 7990). Trondheim: Tapir Akademisk Forlag.

Fielding, M. (2001). Students as Radical Agents of Change. Journal of Educational Change, 
2(2), 123-141.

Fielding, M. (2011). Student Voice and the Possibility of Radical Democratic Education: ReNarrating Forgotten Histories, Developing Alternative Futures. In G. Czerniawski \& W. Kidd (Eds.), The Student Voice Handbook (pp. 3-18). Bingley: Emerald.

Fletcher, A. (2005). Guide to Students as Partners in School Change. soundout.org.

Flutter, J. (2007). Teacher development and pupil voice. Curriculum Journal, 18(3), 343-354.

Forum for Barnekonvensjon. [Forum for the Convention of the Rights of the Child] (2017).

Kidza Har Rett [The Children Have Rights]. Retrieved from

http://forumforbarnekonvensjonen.no/onewebmedia/Kidza har rett.pdf

Gonzalez, T. E., Hernandez-Saca, D. I., \& Artiles, A. J. (2017). In search of voice: theory and methods in K-12 student voice research in the US, 1990-2010. Educational Review, 69(4), 451-473.

Hall, V. (2017). A tale of two narratives: student voice-what lies before us? A tale of two narratives: student voice-what lies before us? Oxford Review of Education, 43(2), 180193.

Hargreaves, A., \& Shirley, D. (2009). The fourth way : the inspiring future for educational change. Corwin Press.

Higham, R., \& Djohari, N. (2018). From voting to engaging: promoting democratic values across an international school network. Oxford Review of Education, 44(6), 669-685.

Keddie, A. (2015). Student voice and teacher accountability: possibilities and problematics. Pedagogy, Culture \& Society, 23(2), 225-244.

Langford, M., \& Kirkeb $\varnothing$, T. L. (2019). Children's Rights Indexes: Measuring Norway's Performance. In M. Langford, M. Skivenes, \& K. H. Søvig (Eds.), Children's Rights in Norway An Implementation Paradox? (pp. 42-106). Oslo: Universitetsforlaget.

Leek, J. (2019). Teachers perceptions about supporting youth participation in schools: Experiences from schools in England, Italy and Lithuania. Improving Schools, 22(2), 
173-190.

Lincoln, Y. (1995). In Search of Students' Voices. Theory Into Practice, 34(2), 88-93.

Lumby, J. (2012). Learner Voice in Educational research. In A. R. J. Briggs, M. Coleman, \& M. Morrison (Eds.), Research Methods in Educational Leadership and Management (pp. 236-248). London: SAGE.

Lundy, L., Kilkelly, U., \& Byrne, B. (2013). Incorporation of the United Nations Convention on the Rights of the Child in Law: A Comparative Review. International Journal of Children's Rights, 21(3), 442-463.

MacBeath, J. (2004). Democratic learning and school effectiveness:are they by any chance related? In J. MacBeath \& L. Moos (Eds.), Democratic Learning: The Challenge to School Effectiveness (pp. 19-51). London: Routledge Falmer.

Mitra, D., Serriere, S., \& Stoicovy, D. (2012). The role of leaders in enabling student voice. Management in Education, 26(3), 104-112.

Moos, L. (2004). Introduction. In J. MacBeath \& L. Moos (Eds.), Democratic Learning: The Challenge to School Effectiveness (pp. 1-18). London: Routledge Falmer.

O'Neill, J. (2018). Voice and the Ethics of Children's Agency in Educational Research. In Roseanna Bourke \& J. Loveridge (Eds.), Radical Collegiality Through Student Voice (pp. 39-54). Springer Singapore.

OECD. (2015). Education spending (indicator). Retrieved from https://data.oecd.org/eduresource/education-spending.htm\#indicator-chart

Pedder, D., \& Mclntyre, D. (2006). Pupil consultation: the importance of social capital. Educational Review, 58(2), 145-157.

Pring, R. (2015). Philosophy of Educational Research (3rd ed.). London: Bloomsbury.

Quaglia, R. J., \& Corso, M. J. (2014). Student Voice: The Instrument of Change. USA: Corwin. Kunnskapsdepartementet [Ministry of Education and Research] (1998, last amended 2018). Act of Education. Retrieved from https://lovdata.no/dokument/NLE/lov/1998-07-17- 


\section{1\#KAPITTEL_6}

Kunnskapsdepartementet [Ministry of Education and Research]. (2016). Meld. St. 21 [Report nr. 21] (2016-2017). Retrieved from https://www.regjeringen.no/contentassets/71c018d2f5ee4f7da7df44a6aae265bc/no/ pdfs/stm201620170021000dddpdfs.pdf

Robinson, C., \& Taylor, C. (2013). Student voice as a contested practice: Power and participation in two student voice projects. Improving Schools, 16(1), 32-46.

Robson, C., \& McCartan, K. (2016). Real World Research. Chichester: John Wiley \& Sons.

Rodgers, C. R. (2006). Attending to Student Voice: The Impact of Descriptive Feedback on Learning and Teaching. Curriculum Inquiry, 36(2), 209-237.

Rudduck, J., \& Fielding, M. (2006). Student voice and the perils of popularity. Educational Review, 58(2), 219-231.

Rudduck, J., \& Mclntyre, D. (2007). Improving Learning through Consulting Pupils. Abingdon: Routledge.

The Ombudsman for Children in Norway. (2017). The UN Convention on the Rights of the Child Suppplementary Report. Retrieved from http://barneombudet.no/wpcontent/uploads/2017/10/bosupplerende_norsk.pdf

Thompson, P. (2009). Consulting secondary school pupils about their learning. Oxford Review of Education, 35(6), 671-687.

Thuen, H. (2017). Den Norske Skole [The Norwegian School]. Oslo: Abstrakt Forlag.

UNICEF. (1989). The United Nations Convention on the Rights of the Child. London.

Utdanningsdirektoratet [Department of Education]. (2015). Ledelse i skolen: Krav og forventninger til en rektor [Leadership in School: Requirements and Expectations towards a Principal]. Retrieved from https://www.udir.no/globalassets/filer/skoleutvikling/rektorutdanning/skoleledere_bo kmaal.pdf 
Utdanningsdirektoratet [Department of Education]. (2018). Overordnet del av læreplanverket [Fundamental Principles of the National Curriculum]. Retrieved October 3, 2019, from https://www.udir.no/laring-og-trivsel/lareplanverket/overordnet-del/

Utdanningsdirektoratet [Department of Education]. (2019). Results from Student Survey. Retrieved from

https://skoleporten.udir.no/rapportvisning/grunnskole/laeringsmiljoe/elevundersoekel sen $/$ nasjonalt ?enhetsid $=00 \&$ vurderingsomrade $=6 \&$ underomrade $=48 \&$ skoletype $=0 \&$ sk oletypemenuid=0\&sammenstilling=1

Woods, D., \& Macfarlane, R. (2017). What makes a great school in the twenty-first century? In P. Earley \& T. Greany (Eds.), School Leadership and Education System Reform (pp. 79-89). London: Bloomsbury. 